The Affective Dimension in Second Language Acquisition 


\section{SECOND LANGUAGE ACQUISITION}

Series Editor: Professor David Singleton, Trinity College, Dublin, Ireland

This series brings together titles dealing with a variety of aspects of language acquisition and processing in situations where a language or languages other than the native language is involved. Second language is thus interpreted in its broadest possible sense. The volumes included in the series all offer in their different ways, on the one hand, exposition and discussion of empirical findings and, on the other, some degree of theoretical reflection. In this latter connection, no particular theoretical stance is privileged in the series; nor is any relevant perspective - sociolinguistic, psycholinguistic, neurolinguistic, etc. - deemed out of place. The intended readership of the series includes final-year undergraduates working on second language acquisition projects, postgraduate students involved in second language acquisition research and researchers and teachers in general whose interests include a second language acquisition component.

Full details of all the books in this series and of all our other publications can be found on http://www.multilingual-matters.com, or by writing to Multilingual Matters, St Nicholas House, 31-34 High Street, Bristol BS1 2AW, UK. 


\section{The Affective Dimension in Second Language Acquisition}

Edited by

Danuta Gabryś-Barker and Joanna Bielska 


\section{Library of Congress Cataloging in Publication Data}

A catalog record for this book is available from the Library of Congress.

The Affective Dimension in Second Language Acquisition/Edited by Danuta Gabrys-

Barker and Joanna Bielska.

Second Language Acquisition: 68

Includes bibliographical references.

1. Second language acquisition-Study and teaching. I. Gabrys, Danuta, editor of compilation.

P118.2.A346 2013

418.0071-dc23 2013002061

British Library Cataloguing in Publication Data

A catalogue entry for this book is available from the British Library.

ISBN-13: 978-1-84769-968-8 (hbk)

\section{Multilingual Matters}

UK: St Nicholas House, 31-34 High Street, Bristol BS1 2AW, UK.

USA: UTP, 2250 Military Road, Tonawanda, NY 14150, USA.

Canada: UTP, 5201 Dufferin Street, North York, Ontario M3H 5T8, Canada.

Copyright (C) 2013 Danuta Gabryś-Barker, Joanna Bielska and authors of individual chapters.

All rights reserved. No part of this work may be reproduced in any form or by any means without permission in writing from the publisher.

The policy of Multilingual Matters/Channel View Publications is to use papers that are natural, renewable and recyclable products, made from wood grown in sustainable forests. In the manufacturing process of our books, and to further support our policy, preference is given to printers that have FSC and PEFC Chain of Custody certification. The FSC and/or PEFC logos will appear on those books where full certification has been granted to the printer concerned.

Typeset by Techset Composition Ltd., Salisbury, UK.

Printed and bound in Great Britain by the MPG PrintGroup Ltd. 